\title{
The Characteristics and the Enlightenments of actual combat teaching of West Point
}

\author{
Zhongmin Liu*, Xiangjun Xu,Zelong Zhou,Shancao Tu \\ Wuhan Mechanical College, Wuhan, 430075, China \\ * Corresponding author. E-mail: 1137645276@qq.com
}

\begin{abstract}
The West Point focus on improving the practical ability of their students, they have formed practical teaching system and method with characteristics. It has propsed some enlightenment for us to promote actual combat teaching and training reform.To meet the actual combat demand, The teaching mode close to the actual combat troops must be implemented. In order to grasp the characteristics of the actual combat, The construction of approximation of actual combat teaching environment must be carried out. Close to the teaching reform needs, teaching faculty with high quality must be brought up.Focusing on the cultivation of fighting spirit, the campus culture of hero theme must be constructed.
\end{abstract}

Key words: West Point, Actual Combat, Enlightenment

\section{INTRODUCTION}

West Point training is famous for serious, strict, harsh in the world, which combines the characteristics of national culture and the army USA, focusing on improving their practical ability, it also has formed the system and the method of practical teaching with characteristics. To study the successful experience and practice of the West Point of actual teaching carefully, it has important inspiration and significance for promoting the reform of our military academies to improve the ability of actual combat cadet practical teaching and training vigorously.

\section{THE CHARACTERISTICS OF THE ACTUAL COMBAT TRAINING IN THE WEST POINT}

West Point of military training is divided into three stages of basic Cadet Training, field training, leadership training, the training time of each stage for 7-9 weeks, the purpose is to make students master the single soldier combat and team leadership skills and related occupation knowledge, cultivate and improve the students leadership and the physical ability, the formation of the value of military occupation view. The basic training phase, implemented in the first year of the summer, in the Buckner camp, the students called the "beast" camps, training subjects are physical training, fire training, fire live ammunition, grenades, group exercises, rope hanging drop weapons team operation, the purpose is to cultivate the students' personal skills, ready to formal learning and training. Here in the west point at with inhuman means, through repeated practice, training, reduce food and sleep, cut social and entertainment cruel training and management, cultivate the students' responsibility, discipline, courage and perseverance qualities such as absolutely obey orders, form style. Field training stage, implemented in the second year of the summer, training subjects include infantry tactics, weapons, artillery firing operation, field communication and rescue, the purpose is to enable students to master the advanced individual skills, establish the consciousness of team cooperation, temper NCO level leadership. Leadership training stage, in the implementation of the third year, until the Cadet leadership after the training, the selection of the students to participate in military training courses, including air assault and various maneuvers and other activities.

West Point says, sports can not only cultivate the students' physical skills, motor coordination, antagonism and self-confidence of quality, more important is to enhance student's collective sense of honor, to cultivate students the spirit of challenge, make students face the difficulties, to withstand pressure, be fearless challenge character. West Point stadium door engraved with Macarthur's famous saying "sow the seeds of friendly competition in the playground today, the future will be in the battlefield has bred the fruits of victory", highly summarizes the essence of West sports. Sports office West Point with 13 people, responsible for the various sports competitions, the establishment of more than 20 school sports team, the football team, basketball team, volleyball team has several times won the national championship. There is an annual intercollegiate tournament between West Point and the Naval Academy, that the fall football. West Point to the traditional event as to cultivate the students' team spirit, fighting spirit and sense of responsibility, the sense of competition, the best time to show the spirit of students. In the game, from beginning to end field students watching the game for his team, cheer, until the end of the game, there is only one goal is "to defeat the opponent". Enable the students to remember the "sports is not just the game", but the group fighting.

West Point, adhering to the "today's leader training the leaders of tomorrow" ideas, the establishment of a reasonable structure, excellent quality of teachers, including teachers accounted for $72.5 \%$ of military, civilian personnel accounted for $27.5 \%$. Military 
instructor mainly from the forces of good commanding officers and staff in scale, for 2-3 years, they have rich practical experience to the troops, new theory, new experience forces into the classroom, to carry out targeted teaching, ensure the teaching focus of actual combat, close to the troops. The term one to, or back to their military positions, or to the University for an advanced degree. Civilian faculty from the university graduates a part in the selection of a part from the government departments, recruitment, 3-5 years, the main teaching science and technology and the humanities knowledge of curriculum, the purpose is to improve the student humanities accomplishment, to widen the students' field of vision. In order to maintain the stability of teachers, the West Point retains the permanent professors about $15 \%$ academic attainments, they can be more than 30 years working in the school, until his retirement.

The school is located at West Point West Town, was Washington's headquarters during the American War of independence, he established the size of 14 positions, the old fort, the fort is still intact, become a beautiful scenery in West Point. The campus of the north, towering Memorial Civil War Memorial "battle monument". The campus of West, Putnam Fort stand tall, overlooking the west campus and the Hudson river. The campus, buildings, squares, roads in the United States the history of the famous military general named, as the Washington building, Eisenhower building, the Grant building, Thayer Road, Mahan building, the Mickey stadium; West's statue stands in the park and wide field around the statue of Macarthur, which stand in the Macarthur Hall on the north end of the square the octagonal small central square, below the low wall engraved with the motto of "West Point: duty honor country". Every morning at five fifty, the campus Plaza just north of special Roffer angle, the first World War a howitzer guns rumbled in the morning, marking the west to start a new day. The thick humanities environment, create to remember history, hero worship campus atmosphere, make students feel the spirit of traditional and West Point, time to "duty, honor, country" in mind, dare to undertake the mission responsibility.

\section{THE ENLIGHTENMENT TO PROMOTE OUR ARMY COLLEGES PRACTICAL TEACHING REFORM}

One is aimed at the post, reconstruction of curriculum system. Closely around the combat operations and NCO positions, promote curriculum change from subject type to situational task type, according to connect with the operational process requirements, to establish specialized core curriculum as the leading, main course is based, elective courses to supplement the "specialization, information, practical" curriculum system. Especially around ordnance repair and protection of theme, give full play to teachers and technical advantages, accelerate the formation of the "new discipline system to meet the actual combat troops,". At the same time, fully understand the important role of physical education on students fighting spirit, team spirit and sense of responsibility, adjust the setting of physical education curriculum, the organic unity of sports and sports competition to make strong physique and honed spirit. Two is the practice forces, optimizing the teaching content. College education to the troops move closer, the key is to solve the teaching content and the Army mission docking problem. To establish and force feedback mechanisms, organization of regular teachers in-depth front-line troops, fully familiar with and master the troops construction demand, regularly invited the troops leadership to carry out emergency operations knowledge lectures; establishment and scientific research unit of communication feedback mechanism, organization of regular teachers to scientific research units to learn new equipment, update enrich professional teaching content, teaching content close to the mission, services, to meet the needs of. Three is close to the demand, the innovation of teaching method. Seminar style teaching theory course open problem of traction, the professional course open teaching practice situation based on task, strengthening technical training refers to one. United Education joint training efforts to increase and force, to carry out teaching to realize the depth of integration, keep step with colleges and universities "teaching" and "use" of the army. Firmly grasp the practical characteristics, constructing the approximation of actual combat teaching environment. One is based on the approximation of actual combat natural environment. Motor, reconnaissance and communication of bad weather and complex terrain impact forces, to exert the combat effectiveness of the army. To carry out the practical teaching, should put students in bad weather conditions, high temperature, alpine, Yu Xue storm, improve students' ability to adapt to the harsh environment of. The two is to build a multidimensional combined operations. To guide the students to stand in the angle of joint operations to use knowledge, thinking, improve quality, cultivate the students' consciousness of joint operations and cooperative engagement capability. Three is the construction of electromagnetic environment changeable. Electromagnetic field and runs through the whole struggle is fierce combat, the complex electromagnetic environment should be built to approximate the actual combat, let the students feel the full spectrum of electromagnetic radiation environment, multi type, high density, and through targeted repair training, continuously improve the students ability of equipment support in complex electromagnetic environment. Four is to create a tight complex battlefield atmosphere. Extensive simulation equipment using automatic target, laser, smoke screen, audio, burst point method and various, create a cruel lifelike combat situation and scene, so that the trainees to experience unusually hard, fierce fighting 
atmosphere, improve the psychological quality to adapt to the.

One is to improve the talent exchange mechanism in military academies. To further smooth the teacher transferring channels from the frontline combat troops, selection of high political quality, rich work experience, language expression capability and good at academic research cadres to education teaching, in order to solve the teachers "troop quality is not high" problem. A twoway communication mechanism dredge institutions and forces, and actively selecting excellent Division brigade commanders to college as a part-time instructor, selecting excellent deputy regiment level cadre as a full-time instructors, hiring a combat experience of the military adviser retired cadres as an adjunct instructor. Two is the establishment of teachers' ability of transition mechanism. According to the demand of teacher training colleges, the establishment of base in the army and training base, and make the specification of learning plan, organization, management, security, the formation of teacher normalized to the troops on behalf of mechanism. The introduction of teachers to the troops on behalf of provisions, and to any agency duty experience and promotion, evaluation of specialized technical posts linked. Exercise on the Faculty of the daunting task of military, give full play to United Education joint training mechanism, organize teachers follow army major military action, provided the conditions for improving the overall quality of teachers. Three is to improve the teachers to go abroad for further study the mechanism of. Select outstanding teachers to the foreign army college learning, broaden their horizons, broaden the thinking, to accept new ideas and new concepts, learn from foreign advanced, the accumulation of practical experience.

Focus on the cultivation of fighting spirit, the construction of the campus culture hero theme. The fighting spirit is the comprehensive reflection of ideal and belief, soldier's fighting style, will quality, directly affect and dominate the army, is the decisive factor in the battle force factors. The tenacious fighting spirit culture is the Revolutionary Military "serving the country", "dedication to the mission" of the inherent requirements. To strengthen the construction of campus culture, create good atmosphere for the worship of heroes and revolutionary martyrs, is beneficial to cultivating students fighting spirit. We should improve the understanding on the construction of campus culture, from West Point campus culture construction practice, the formation of ideas of military culture construction with the characteristics of the PLA, do the "two show": one is to highlight the combat characteristics. To render the martial atmosphere, make the combat penetrated into the construction of campus culture of each surface, prevent one-sided pursuit of lighting, landscaping, comfortable, despise the masculine, martial, martial, let the students in the thick military atmosphere, strengthen the fighting consciousness. Two is to highlight the personality characteristics. Not only bear the fine traditions of our army military academy, and inheriting the historical origin, the organic integration of military culture, integrating educational concept, subject characteristics, characteristics and cultural background and other factors, the formation of unique military culture connotation, highlight the unique personality characteristics.

\section{CONCLUSIONS}

This paper presents the characteristics and the enlightenments of actual combat teaching of West Point and some strategies on actual combat in NCO institutions are proposed. College training must move closer to the troops, to move closer to the battlefield combat focused aim of winning, Trainig in a way near the actual war will provide an effective platform for the NCO school students to grasp the method to achieve their victory.

\section{Acknowledgement}

This project is supported by Teaching Reform Funding of Wuhan Mechanical Technology College.

\section{References}

[1] Chen Gang. West Point students comprehensive quality cultivation and Enlightenment of [J]. Journal of PLA University of Science and Technology (Comprehensive Edition), 2008, (4).

Chen Ningjun. On American West Point talent training characteristics of [J]. command Sinica, 2004, (4) 